\title{
Conductometric biosensor based on whole-cell microalgae for assessment of heavy metals in wastewater
}

\author{
A. L. Berezhetskyy ${ }^{1,2,4}$, C. Durrieu' ${ }^{2}$ H. Nguyen-Ngoc ${ }^{3}$, J.-M. Chovelon ${ }^{4}$, \\ S. V. Dzyadevych ${ }^{1}$, C. Tran-Minh ${ }^{5}$
}

\author{
${ }^{1}$ Institute of Molecular Biology and Genetics, National Academy of Sciences of Ukraine \\ Academician Zabolotnoho str., 150, Kyiv, 03680 Ukraine \\ ${ }^{2}$ Ecole Nationale des Travaux Publics de l'Etat, Laboratoire des Sciences de l'Environnement \\ Vaulx-en-Velin, France \\ ${ }^{3}$ University of Technology HCM \\ 268 rue Ly Thuong Kiet, Ho Chi Minh, Vietnam \\ ${ }^{4}$ Universite Claude Bernard Lyon 1, IRCELYON UMR-CNRS 5256, Institut de Recherches sur la Catalyse et l'Environnement de Lyon \\ Villeurbanne, France \\ ${ }^{5}$ Ecole Nationale Superieure des Mines de Saint-Etienne \\ Saint-Etienne, France \\ berezhetsky@yahoo.com
}

\begin{abstract}
Whole-cell Chlorella vulgaris conductometric biosensors consisting of gold planar interdigitated electrodes and sol-gel algal membranes have been used for assessment of heavy-metal ions in water. These analytes act as algal alkaline phosphatase inhibitors. Enzyme residual activity has been measured in Tris-nitrate buffer in the presence of $\mathrm{Mg}^{2+}$ ions as activator. Operating conditions of this biosensor have been optimized and its characteristics are discussed. Detection limits are about $1 \mathrm{ppb}$ for $\mathrm{Cd}^{2+}, \mathrm{Co}^{2+}, \mathrm{Ni}^{2+}$, $\mathrm{Pb}^{2+}$ and $10 \mathrm{ppb}$ for $\mathrm{Zn}^{2+}$. The storage stability of the biosensor in buffer solution at $4{ }^{\circ} \mathrm{C}$ is more than 40 days. The biosensor has been used to assess wastewater pollution.
\end{abstract}

Keywords: Chlorella vulgaris, thin-film planar interdigitated electrodes, sol-gel immobilization, inhibitor analysis.

Introduction. The application of biosensors for determination of toxic compounds is a dynamic trend in sensor research. These sensors seem to be very promising since analytical systems based on them are simple, rapid, and selective. They can be of great use for air and water environmental control, food analysis, medicine and industry, in particular as regards to heavy metal ions, which are known to be harmful pollutants. Heavy-metal ions toxicity to living organisms was

(C) A. L. BEREZHETSKYY, C. DURRIEU, H. NGUYEN-NGOC,

J.-M. CHOVELON, S. V. DZYADEVYCH, C. TRAN-MINH, 2007 explained by their fixation on the thiol groups of enzymes. This is the case of alkaline phosphatase (AP) which is known to be inhibited by this kind of pollutants [1].

The development of a multi-enzymatic biosensor for the detection of different groups of pollutants represents an important challenge. However, a biosensor using different enzymes on a multisensor array cannot operate in optimal conditions, since they may be different from one enzyme to the other. Other problems including enzyme stability and enzyme purification cost must also be overcome. The use of 


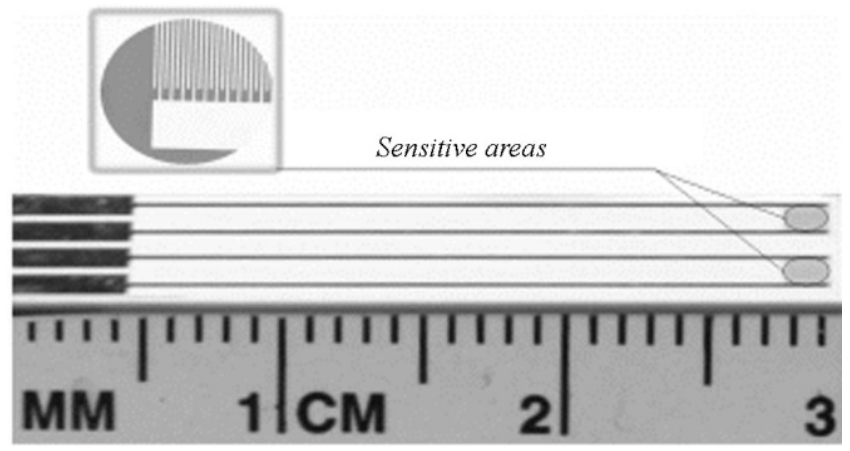

Fig. 1. The view of a conductometric microtransducer

whole cells or microorganisms to produce a multi-enzymatic biosensor can be a good solution, since they contain a large number of enzymes. Moreover, ecotoxicological information can be obtained from the effects of pollutants on these living organisms.

Among the tested immobilizing techniques used by our team there are glutaraldehyde cross linking, calcium alginate and agarose gel entrapments, pyrrol-alginate gel electropolymerization [2-4]. All these methods are unsuitable for our application because of physical and chemical instability and/or back side reactions.

Silica matrixes are relatively inexpensive to synthesize and have interesting properties including biocompatibility and chemical inertness [5]. Special features of such systems are great possibilities of the variation of the physical, chemical, and functional properties of materials with the identical or close composition of the reaction products. Sol-gel based membranes also reduce side reactions compared to conventional supports.

In this communication, the sol-gel technique has been used to construct a conductometric biosensor based on thin-film planar interdigitated microelectrodes. The main benefits of such microsensors are small size, high sensitivity, and low power consumption [6].

Thus, the aim of our work was to create a conductometric biosensor for heavy metal ions determination based on entrapped in sol-gel whole cells of Chlorella vulgaris as a sensitive element.

Materials and Methods. Chemicals. Silica sources were sodium silicate solutions (purchased from
Riedel-de-Haen) and colloidal silica LUDOX HS-40 («Aldrich», USA). All other reagents were purchased from «Sigma» (USA). $\mathrm{Zn}, \mathrm{Cd}, \mathrm{Co}, \mathrm{Ni}$, and $\mathrm{Pb}$ nitrates were used as analytes. All chemicals were of analytical grade. AP substrate solutions of p-nitrophenylphosphate disodium salt ( $\mathrm{pNPP}$ ) were prepared immediately before use.

Cell culture. The C. vulgaris strain (CCAP 211/12) was purchased from The Culture Collection of Algae and Protozoa at Cumbria (United Kingdom). The axenic algal strain was grown in the culture medium and under conditions described by the International Organization for Standardization (ISO 8692) [7].

Sensor design. Fig. 1 shows the planar conductometric transducer. Two identical pairs of gold interdigitated electrodes (thickness $0.5 \mu \mathrm{m}$ dimensions $5 \times 30 \mathrm{~mm}$ ) were fabricated by vacuum deposition on a ceramic substrate (sintered aluminum oxide) at the Institute of Semiconductor Physics, Kyiv, Ukraine. An intermediate layer of chromium $(0.1 \mu \mathrm{m}$ thick) was used for better gold adhesion. Each finger of the electrode was $20 \mu \mathrm{m}$ wide and $1 \mathrm{~mm}$ long, with $20 \mu \mathrm{m}$ spacing between fingers of the electrode in the pair. The sensitive area of each electrodes pair was about $1 \times 1.5$ $\mathrm{mm}$. To define the sensitive area of the transducer, the central part of the chip was covered with epoxy resin.

Cell entrapment. Sodium silicate $(0.4 \mathrm{M}, 4 \mathrm{ml})$ and colloidal silica LUDOX (8.5 M, $4 \mathrm{ml})$ were thoroughly mixed $(300 \mathrm{rpm})$ to obtain a homogeneous silica solution. $\mathrm{An} \mathrm{HCl}, 4 \mathrm{M}$ solution was then added drop by drop until an appropriate $\mathrm{pH}$ was reached to induce the gelation process. Before gelation, an algal suspension containing $3 \cdot 10^{8}$ cells $/ \mathrm{ml}$ and $10 \%(\mathrm{w} / \mathrm{w})$ glycerol was introduced under stirring. The resulting solution was deposited on the sensitive surface of the measuring pair of electrodes by the drop method $(0.15 \mu \mathrm{l})$ to produce silica matrixes containing algal cells. The measuring pair of electrodes was covered with an AP active algal membrane, while the reference pair used algal cells with no AP activity. Gelation occurred within about $5 \mathrm{~min}$ at room temperature. Wet gels were aged for 24 hours at $4{ }^{\circ} \mathrm{C}$ in the mother solution in a closed flask in order to ensure gel densification before analysis [8].

Measurements. Conductometric measurements were performed by applying to each pair of interdigitated electrodes a small-amplitude alternating 


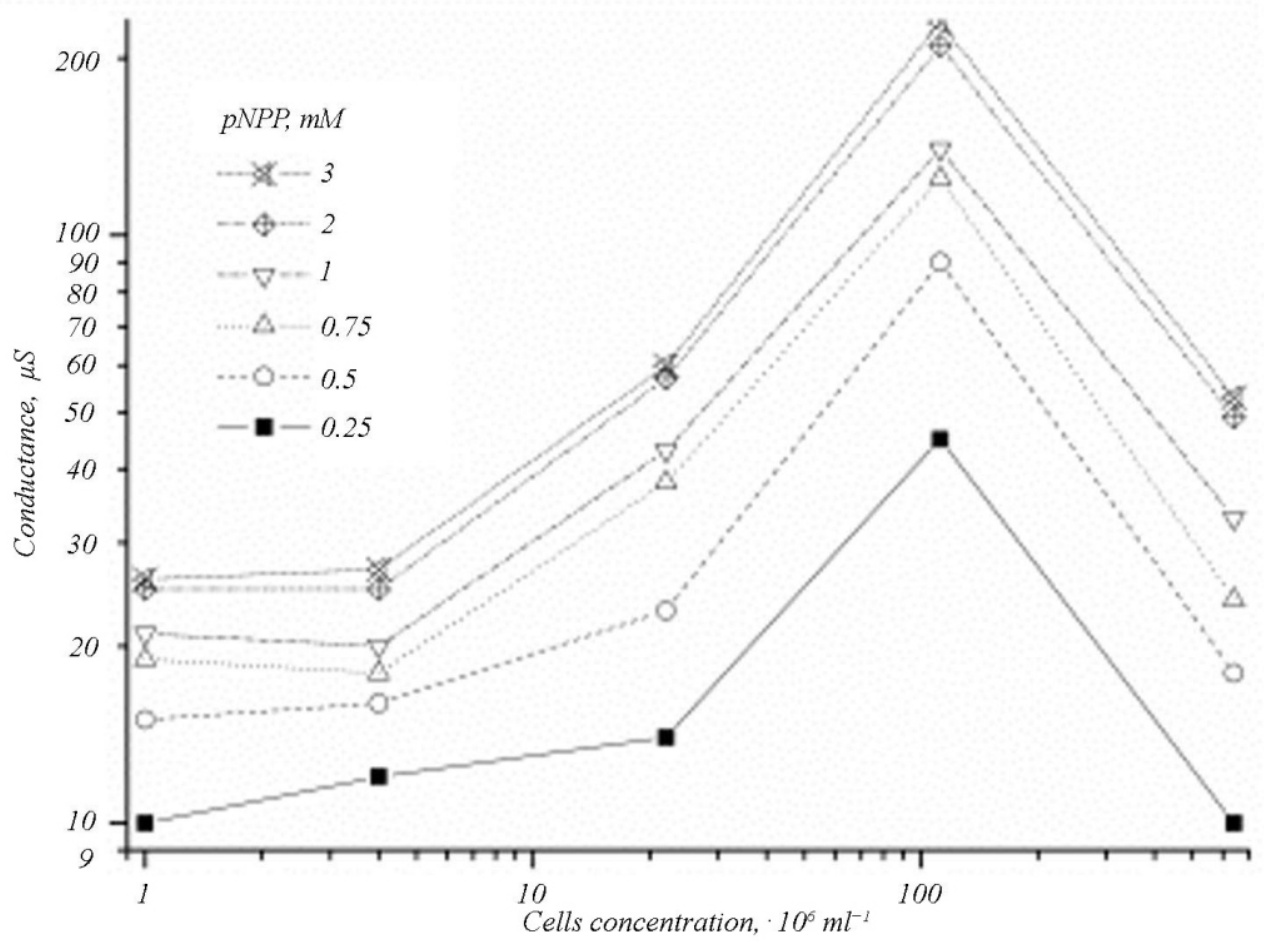

Fig. 2. Dependence of conductometric biosensor response on algal cells concentration in sol-gel membrane for different pNPP concentrations. Measurements were conducted in $1 \mathrm{mM} \mathrm{Mg}\left(\mathrm{NO}_{3}\right)_{2}$ with $10 \mathrm{mM}$ Tris-nitrate buffer, $\mathrm{pH} 8.5$ voltage $10 \mathrm{mV}$ with $100 \mathrm{kHz}$ frequency generated and analyzed by SR-830 DSP lock-in amplifier, Standford research systems, UK [9]. The substrate concentration was increased step-wise by adding defined volumes of appropriate concentrated solutions. The conductivity changes resulted from the enzymatically catalyzed hydrolysis of pNPP. The AP inhibition by heavy-metal ions resulted in a reduction of the biosensor sensitivity to substrate. All measurements were carried out under stirring at room temperature in a $2 \mathrm{ml}$ glass cell filled with working medium: $1 \mathrm{mM} \mathrm{Mg}\left(\mathrm{NO}_{3}\right)_{2}$, as $\mathrm{AP}$ activator, with $10 \mathrm{mM}$ Tris-nitrate buffer, $\mathrm{pH} 8.5$ [10]. Biosensors were prepared each day and stored at $4{ }^{\circ} \mathrm{C}$ between experiments. Storage was conducted in the culture medium without phosphate ions to avoid AP activity loss and cells growth [11, 12]. Wastewater, collected in Chevire (France), was sterilized before experiment at $130{ }^{\circ} \mathrm{C}, 1.5$ bar to suppress contaminating bacterial phosphatase activity.

Results and Discussions. Described algal conductometric biosensor is based on the following reaction:

$$
\mathrm{XPO}_{3}{ }^{2-}+\mathrm{H}_{2} \mathrm{O} \stackrel{\text { phosphatase }}{\longrightarrow} \mathrm{XH}+\mathrm{HPO}_{4}{ }^{2-},
$$

where $\mathrm{XPO}_{3}^{2-}$ is the organic phosphate substrate and $\mathrm{HPO}_{4}^{2-}$ - the monohydrophosphate.

When paranitrophenyl phosphate is used as a substrate, the product $\mathrm{XH}$ is paranitrophenol.

Therefore, in the presence of alkaline phosphatase, the reaction induces a change in $\mathrm{pH}$ and in conductivity. The change in conductivity can be detected with a conductometric microtransducer. This electrochemical method is based on measuring conductivity change of the analyzed medium. In our case, conductivity change results from enzymatic reaction, enzyme activity, and also depends on the physical and chemical properties of reaction medium.

The first step of this work was to optimize the biosensor response as a function of algal concentrations in the membrane (Fig. 2).

As for the algae concentrations in the membranes of described biosensor, there is the optimal concentration i. e. $(30 \div 300) \cdot 10^{6}$ cells $/ \mathrm{ml}$. It was observed that the signal amplitude decreased at higher algae concentrations. In this case enzymatic reactions can only occur on the border of the membranes preventing substrate molecules from diffusing inside and reacting with algae situated near the sensitive areas. As a consequence, a low signal was observed. Moreover, 


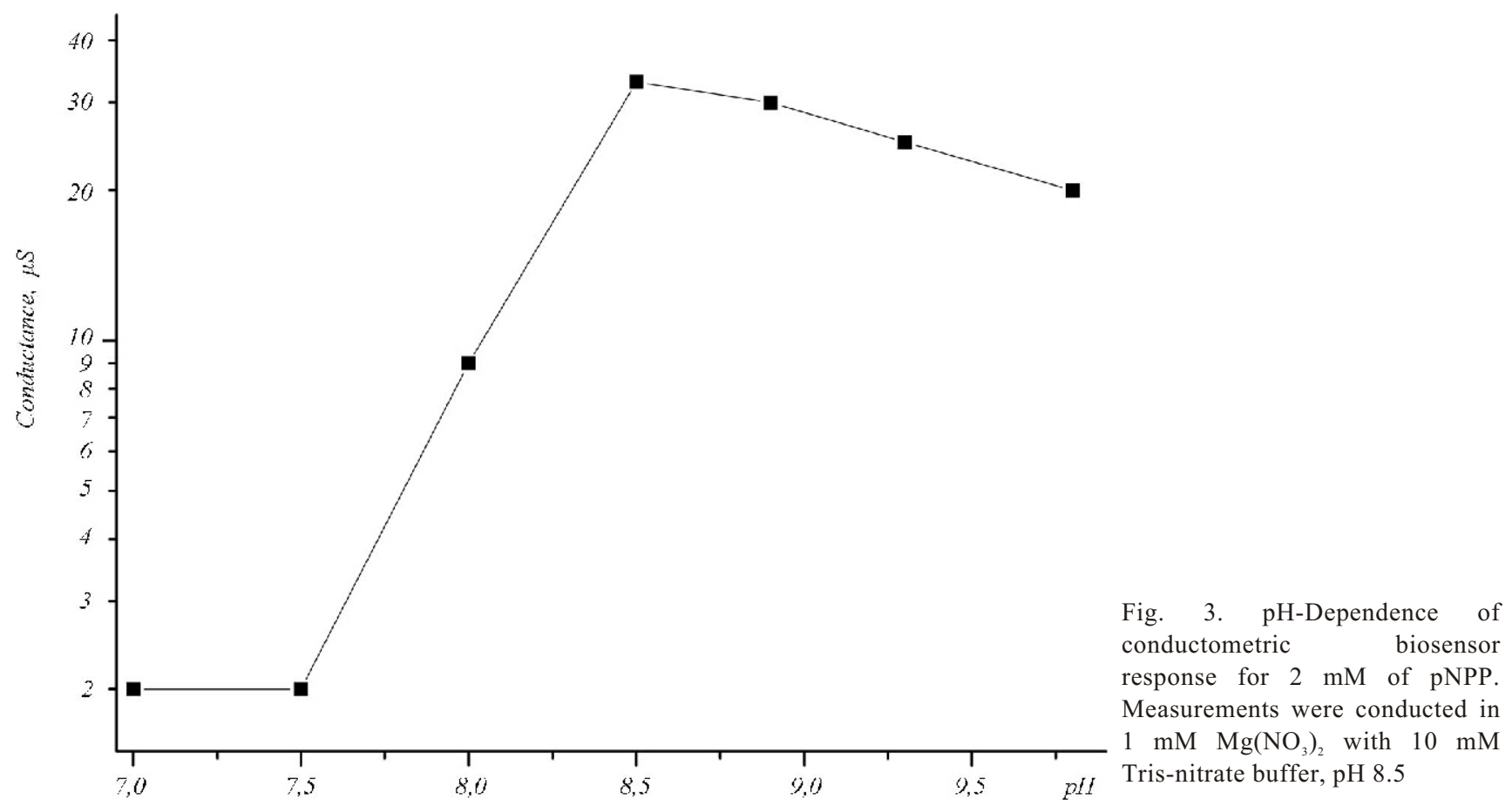

lower algae concentrations in membranes also give slight conductivity variations since only a few substrate molecules can be transformed. It is interesting to note that for enzyme biosensors the same conclusion has already been done [13].

Influence of substrate concentrations on biosensor sensitivity to $\mathrm{Cd}^{2+}$ concentration has already been observed. If the substrate concentration is small, the signal amplitude is too small to be measured properly. If it is higher, the sensitivity to inhibitors decreases. The concentration of $2 \mathrm{mM}$ in pNPP was chosen to prepare our biosensor for heavy metals determination since it provides the sufficient stable signal to substrate with rather a good sensitivity to heavy metals.

It is well known that enzyme activity and optimal $\mathrm{pH}$ are changed after immobilization particularly when the enzymatic reaction changes the $\mathrm{pH}$ of the medium.

Fig. 3 shows the dependence of algal AP activity on $\mathrm{pH}$ when the cells are immobilized on the conductometric transducer. Enzyme activity of C. vulgaris is maximal for $\mathrm{pH} 8.5$ for our biosensor response to substrate, while it was reported 10.5 for the algae in suspension [10].

Ionic strength is one of the most influential parameters in conductometric assays, since the ionic species, charges and mobilities are detected using conductometric measurements. The biosensor response to $2 \mathrm{mM}$ substrate was measured as a function of $\mathrm{KNO}_{3}$ concentrations (Fig. 4).

High $\mathrm{KNO}_{3}$ concentrations produce significant background ions interferences and reduce response to pNPP by decreasing the amplitude of the enzymatic signal.

The biosensor is relatively stable for 40 days under storage conditions (Fig. 5).

Good correlation in terms of AP storage stability was found between the biosensor and the cells suspension [10].

Fig. 6 shows the percentage of AP inhibition as a function of various metal ions concentrations. Inhibition of AP was found for ppm concentration levels of tested metals while activation of AP activity occurs at ppb concentration levels, except for $\mathrm{Zn}$. The activation could be explained by cellular stress: indeed, to prevent the cell from heavy-metals damages, stress promoters are produced inducing an increase of some enzymatic activities [14].

The biosensor was used for the assessment of wastewater pollution by heavy-metals. Measurements were carried out after exposures to different 

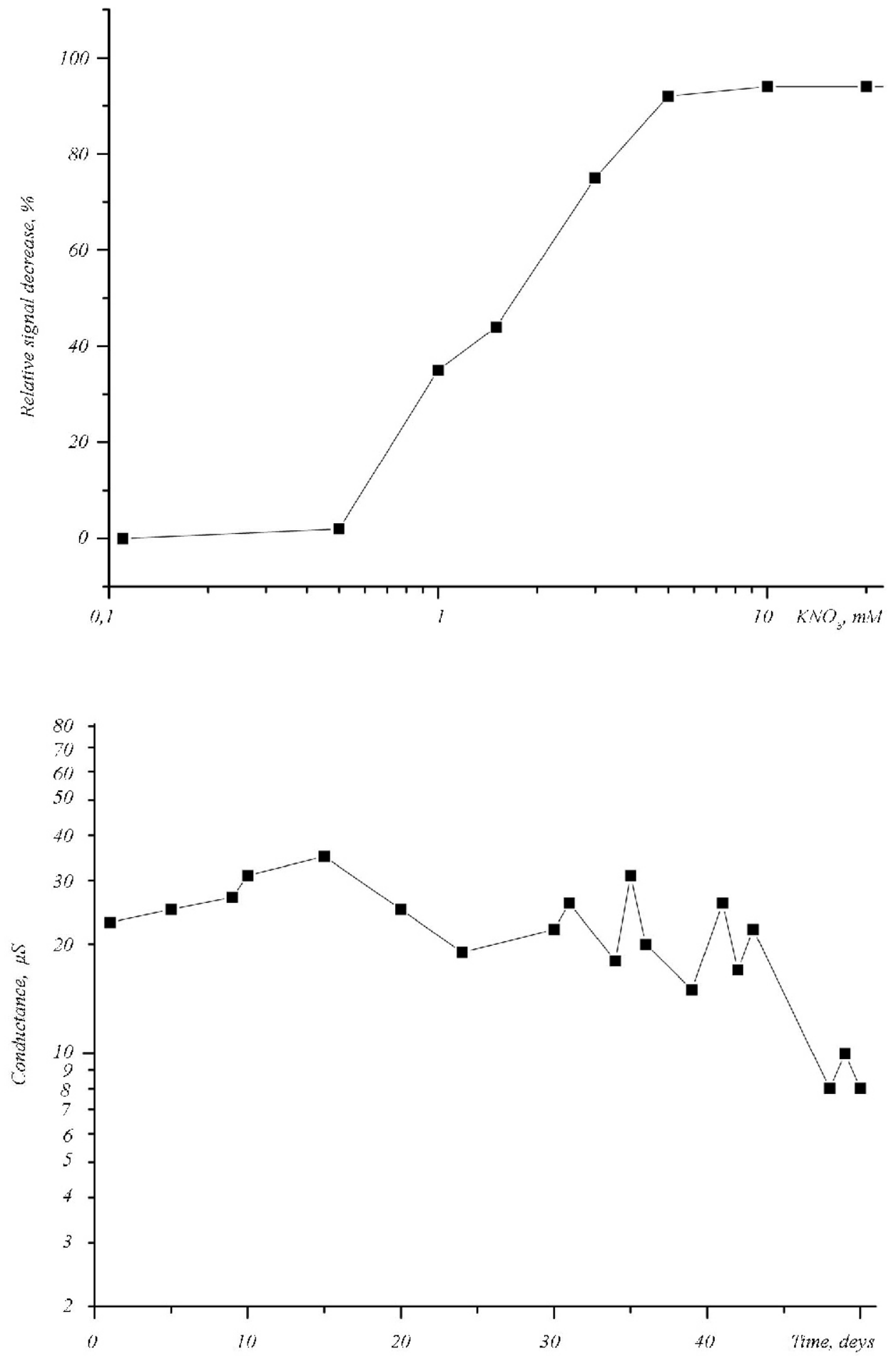

Fig. 4. Dependence of conductometric biosensor relative signal decrease on ionic strength for $2 \mathrm{mM}$ pNPP. Measurements were conducted in $1 \mathrm{mM}$ $\mathrm{Mg}\left(\mathrm{NO}_{3}\right)_{2}$ with $10 \mathrm{mM}$ Tris-nitrate buffer, $\mathrm{pH} 8.5$
Fig. 5. Dependence of the algal biosensor response on storage life for $2 \mathrm{mM}$ pNPP. Measurements were conducted in $1 \mathrm{mM} \mathrm{Mg}\left(\mathrm{NO}_{3}\right)_{2}$ with $10 \mathrm{mM}$ Tris-nitrate buffer, pH 8.5 concentrations of the wastewater in the working medium. Fig. 7 shows the percentage of AP inhibition as a function of different wastewater concentrations. Table shows concentration of some heavy metals ions found in the wastewater using atomic absorption spectroscopy as a reference method. For the lowest concentrations of tested wastewater the activation of AP activity was obtained due to the low concentration 
Concentration of heavy metal ions found in the wastewater using atomic absorption spectroscopy

\begin{tabular}{l|l|c|c|c}
\multicolumn{5}{|c}{ Concentration of heavy metal ions, ppm } \\
\hline $\mathrm{Zn}^{2+}$ & $\mathrm{Pb}^{2+}$ & $\mathrm{Co}^{2+}$ & $\mathrm{Ni}^{2+}$ & $\mathrm{Cd}^{2+}$ \\
\hline 740 & 46.6 & 146 & 3.30 & 0.23 \\
\hline
\end{tabular}
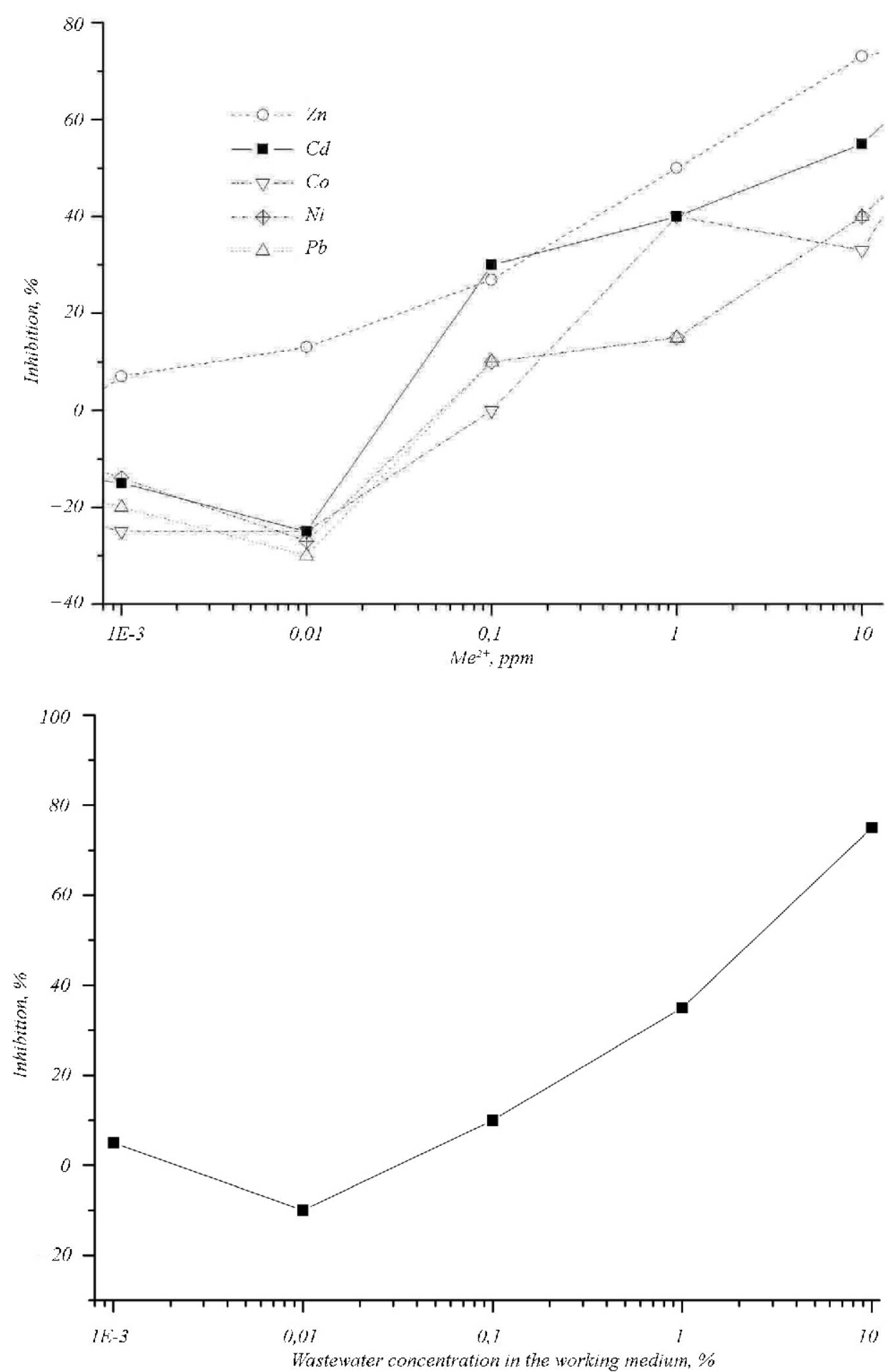

Fig. 6. Calibration curves of conductometric algal biosensor for different metal ions. Measurements were conducted in $1 \mathrm{mM}$ $\mathrm{Mg}\left(\mathrm{NO}_{3}\right)_{2}$ with $10 \mathrm{mM}$ Tris-nitrate buffer, $\mathrm{pH} 8.5$
Fig. 7. Evolution of alkaline phosphatase activity rate after exposure at different concentrations of wastewater detected with conductometric biosensor. Measurements were conducted in $1 \mathrm{mM} \mathrm{Mg}\left(\mathrm{NO}_{3}\right)_{2}$ with $10 \mathrm{mM}$ Tris-nitrate buffer, $\mathrm{pH} 8.5$ 
of metal ions. For higher concentrations of heavy metal ions in wastewater samples at lower dilution a good correlation was obtained between concentration of samples and inhibition rate.

Conclusions. AP conductometric biosensors consisting of interdigitated gold electrodes and algae entrapped in sol-gel membranes formed on their sensitive parts have been used for the assessment of water pollution with heavy metals ions.

Optimal algal concentrations in the membranes of the described biosensor were about $(30 \div 300) \cdot 10^{6}$ cells/ml. Optimal $\mathrm{pH}$ of the biosensors working medium was 8.5.

Detection limits were about $1 \mathrm{ppb}$ for $\mathrm{Cd}^{2+}, \mathrm{Co}^{2+}$, $\mathrm{Ni}^{2+}, \mathrm{Pb}^{2+}$ and $10 \mathrm{ppb}$ for $\mathrm{Zn}^{2+}$. The storage stability of the biosensor was more than 40 days.

The sensitivity of the biosensor to ionic strength is rather high for all conductometric sensors and can be decreased with additional permselective membranes [15]. The described conductometric biosensor was successfully used for the assessment of water pollution with heavy-metals. Further development will include searching for ways to improve selectivity to heavy metal ions using multi-enzymatic biosensors arrays and multivariable correspondence analysis [16].

Acknowledgements. A part of this work was financially supported by National Academy of Sciences of Ukraine in the frame work of Scientific and Technical Program Sensors systems for medical-ecological and industrial-technological problems. A part of this work also was supported by fellowships of French Embassy in Ukraine and also MIRA, Rhone-Alpes region (to A. L. Berezhetskyy).

А. Л. Бережеиький, К. Дюрьє, Х. Нгуен-Нгок, Ж.-М. Шовелон, С. В. Дзядевич, К. Тран-Мин

Кондуктометричний біосенсор на основі мікроводоростей для оцінки вмісту важких металів у стічних водах

Резюме

Описано біосенсор для оцінки вмісту важких металів у воді. Для його створення клітини Chlorella vulgaris іммобілізували на золотих планарних гребінчастих електродах за допомогою золь-гель технології. Важкі метали є інгібіторами лужної фосфатази. Залишкову активність іммобілізованого ферменту вимірювали в трис-нітратному буферному розчині за присутності активатора - іонів магнію. Оптимізовано робочі характеристики біосенсора. Нижня межа визначення склада-

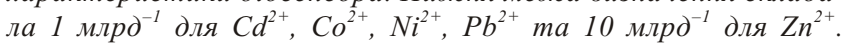

Термін зберігання біосенсора у буферному розчині за температури $4{ }^{\circ}$ С був більшим, ніж 40 діб. Біосенсор використано для оцінки забруднення важкими металами стічних вод.

Ключові слова: Chlorella vulgaris, тонкоплівкові планарні гребінчасті електроди, золь-гель іммобілізація, інгібіторний аналіз.

\section{А. Л. Бережецкий, К. Дюрье, Х. Нгуен-Нгок, Ж.-М. Шовелон,} С. В. Дзядевич, К. Тран-Мин

Кондуктометрический биосенсор на основе микроводорослей для оценки содержания тяжелых металлов в сточных водах

Резюме

Описан биосенсор для оценки содержания тяжельх металлов в воде. Для его создания клетки Chlorella vulgaris иммобилизировали на золотых планарных гребенчатых электродах с помошью золь-гель технологии. Тяжелье металлы являются ингибиторами щелочной фосфатазы. Остаточную активность иммобилизованного фермента измеряли в трис-нитратном буферном растворе в присутствии активатора: ионов магния. Оптимизированы рабочие характеристики биосенсора. Нижняя граница определения составляла 1 млрд $\partial^{-1}$ для $\mathrm{Cd}^{2+}, \mathrm{Co}^{2+}, \mathrm{Ni}^{2+}, \mathrm{Pb}^{2+}$ u 10 млрд ${ }^{-1}$ для $\mathrm{Zn}^{2+}$. Срок хранения биосенсора в буферном растворе при температуре $4{ }^{\circ} \mathrm{C}$ составляет более 40 дней. Биосенсор использован для оиенки загрязнения тяжельми металлами сточных вод.

Ключевые слова: Chlorella vulgaris, тонкопленочные планарные гребенчатые электроды, золь-гель иммобилизация, ингибиторный анализ.

\section{REFERENCES}

1. Webb J. L. Enzyme and metabolic inhibitors.-New York: Acad. press, 1966.-729 p.

2. Chouteau C., Dzyadevych S. V., Chovelon J.-M., Durrieu C. Development of novel conductometric biosensors based on immobilised whole cell Chlorella vulgaris microalgae // Biosensors and Bioelectronics.-2004.-19, N 9.-P. 10891096.

3. Chouteau C., Dzyadevych S. V., Chovelon J.- M., Durrieu C. A bi-enzymatic whole cell conductometric biosensor for heavy metal ions and pesticides detection in water samples // Biosensors and Bioelectronics.-2005.-21, N 2.-P. 273-281.

4. Ionescu R. E., Abu-Rabeah K., Cosnier S., Durrieu C., Chovelon J.-M., Marks R. S. Amperometric algal Chlorella vulgaris cell biosensors based on alginate and polypyrrole-alginate gels // Electroanalysis.-2006.-18, N 11.-P. 1041-1046.

5. Nguyen-Ngoc H., Tran-Minh C. Sol-gel process for vegetal cell encapsulation // Mater. Sci. Eng., C.-2007.-27.P. 607-611.

6. Dzyadevych S., Arkhypova $V$., Korpan Y., El'skaya A., Soldatkin A., Jaffrezic-Renault N., Martelet C. Conductometric formaldehyde sensitive biosensor with specifically adapted analytical characteristics // Anal. Chim. Acta.-2001.-445, N 1.-P. 47-55. 
7. ISO 8692 Water quality: fresh water growth inhibition test with Scenedesmus subspicatus and Selenastrum capricornutum // Int. Organization for Standardization, 1989.

8. Nassif N., Roux C., Coradin T., Bouvet O., Livage J. Bacteria quorum sensing in silica matrices // J. Mater. Chem.-2004.14.-P. 2264-2268.

9. Xuejiang W., Dzyadevych S. V., Chovelon J.-M., JaffrezicRenault N., Ling C., Siqing C., Jianfu Z. Conductometric nitrate biosensor based on methyl viologen/Nafion $\mathbb{R} /$ nitrate reductase interdigitated electrodes // Talanta.-2006.-69.P. 450-455.

10. Badreddine I. Mise au point d'un test de toxisite base sur la mesure de la phosphatase alcaline de microphytes. These biologie et biochmie apliquees.-Chambery: Univ. de Savoie, 1996.-136 p.

11. Nassif N., Roux C., Coradin T., Rager M. N., Bouvet O. M., Livage $J$. A sol-gel matrix to preserve the viability of encapsulated bacteria // J. Mater. Chem.-2003.-13.P. 203-208.

12. Durrieu C., Tran-Minh C. Optical algal biosensor using alkaline phosphatase for determination of heavy metals // Ecotoxicol. Environ. Saf.-2002.-51, N 3.-P. 206-209.
13. Mai Anh T., Dzyadevych S. V., Soldatkin A. P., Duc Chien N., Jaffrezic-Renault N., Chovelon J.-M. Development of tyrosinase biosensor based on $\mathrm{pH}$-sensitive field-effect transistors for phenols determination in water solutions // Talanta.-2002.-56.-P. 627-634.

14. Olabarrieta I., L'Azou B., Yuric S., Cambar J., Cajaraville $M$. P. In vitro effects of cadmium on two different animal cell models // Toxicol. in Vitro.-2001.-15.-P. 511-517.

15. Trebbe U., Niggemann M., Cammann K., Fiaccabrino G. C., Koudelka-Hep M., Dzyadevich S. V., Shulga O. A new calcium-sensor based on ion-selective conductometric microsensors - membranes and features // Fresenius J. Anal. Chem.-2001.-371.-P. 734-739.

16. Arkhypova V. N., Dzyadevych S. V., Soldatkin A. P., El'skaya A. V., Jaffrezic-Renault $N$., Jaffrezic $H$., Martelet $C$. Multibiosensor based on enzyme inhibition analysis for determination of different toxic substances // Talanta.-2001.-55.-P. 919-927.

УДК 577.15:543.555

Надійшла до редакції 14.09.07 